\title{
Die bydrae van 'n haalbare gasvryheids- en ontmoetingsetiek in die etiese versorging van gesondheidsorgwerkers
}

\author{
Lategan, Laetus \\ Central University of Technology, Free State \\ llategan@cut.ac.za \\ Burggraeve, Roger \\ KU Leuven, België \\ Vanlaere, Linus \\ Zorg-Ethisch Lab VZW, België
}

\begin{abstract}
The contribution of a doable hospitality and engagement ethics in the ethical care of healthcare workers

The authors of this study advocate for the contribution a double ethic of hospitality and engagement can make towards the ethical care of healthcare workers. Their contribution is based on two studies in healthcare. The South African case outlines challenges with regard to resources, communication and expectations. The Belgium case study draws attention to the traditional approach and suggests a new paradigm, namely to respect the patient as subject and therefore the importance of meeting the patient in his/her situation. Both cases sensitise the reader to the ethical vulnerability of the healthcare worker suggesting that a double ethic of hospitality and engagement is needed to address this challenge. The question of ethical coaching is addressed via a real life example in which the healthcare workers are placed in a simulation laboratory and then treated as "patients" by other healthcare workers. This simulation gives insight into the real needs of patients and how healthcare workers should care for them.
\end{abstract}

Keywords

Care ethics, Doable ethics, Engagement ethics, Hospitality ethics

\section{Agtergrond}

Twee onlangse studies - een uit Suid-Afrika en een uit België - oor die invloed van etiese uitdagings in die gesondheidsorg onderskeidelik op die individu en die praktyk van gesondheidsorg het weer die vraag laat 
ontstaan of bestaande etiese kodes voldoende die etiese uitdagings van die gesondheidsorgwerkers begelei?

Maria Phalime skryf haar boek, Postmortem: the doctor who walked away (2014), uit 'n Suid-Afrikaanse konteks. Haar boek belig die spanning tussen persoonlike ambisie en verwagtings as dokter en die etiese vereistes van mediese optrede (byvoorbeeld moet nie leed aandoen nie, bevorder primêre gesondheidsorg). Die konteks van gesondheidsorg (onvoldoende menslike en finansiële hulpbronne, infrastruktuur en toerusting) maak roeping en etiese optrede moeilik (onmoontlik?). Die uitdagings wat gestel word, word nie deur die beskikbare hulpbronne aangespreek nie. Die verwagtings wat bestaan, is net te véél en uiteenlopend. Sy noem verskeie voorbeelde: Mense versoek siekverlofsertifikate omdat hulle nie meer vakansieverlof beskikbaar het nie. Probleme rondom die HIV/Vigs beleid en die beskikbaarheid van medikasie mak die beoefening van gesondheidsorg moeilik. Geslagsongelykheid, die toenadering van manlike pasiënte teenoor vroulike dokters en die vrees om tuberkulose op te doen, is alles moeilike uitdagings om die hoof te bied. Hierdie omstandighede het by haar die gevoel van magteloosheid gelaat - soveel so dat sy die mediese beroep verlaat het. Phalime (2014:202) verwoord die uitdagings as volg: "Like so many other doctors who have left, medicine still occupies a special place in my heart ... The medical profession places huge demands on doctors. This is not a purely South African phenomenon; it is common to medicine as a whole. Has the time not come for us to look at how we can preserve the best practices in the profession while getting rid of what no longer works?"

Uit België kom 'n studie van Vanlaere en Burggraeve (2013), Gekkenwerk: kleine ondeugden voor zorgdragers. Hierin verbreek die skrywers die tradisionele siening van gesondheidsorgetiek. Hoewel die konteks België is, is die uitdagings internasionaal (soos hierbo opgemerk deur Phalime). Waar die siening tradisioneel bestaan dat gesondheidsorgwerkers altyd etiese korrek moet optree, betoog hulle juis dat die "kleine ondeugde" hieraan reg kan laat geskied om drie redes: Eerstens is gesondheidsorgwerkers ook eties feilbaar en het hulle ook etiese begeleiding en versorging nodig. Tweedens wil die afwesigheid van tradisionele gedrag die lig laat val op die etiese protes teen die onrealistiese verwagtings en vereistes wat aan gesondheidsorgwerkers gestel word. Derdens is etiese keuses 
en gedrag nie altyd wat verwag word nie, maar 'n realistiese oordeel oor wat in 'n betrokke situasie haalbaar is. Teen hierdie agtergrond word "professionele ongehoorsaamheid" bespreek. Die betekenis hiervan is dat gesondheidsorgwerkers deur hulle optrede wys dat hulle nie kan versoen met die gesondheidsorgbeleid of hoe dit binne gesondheidsorgorganisasies gaan nie.

Hierdie professionele ongehoorsaamheid vind sy oorsprong in situasies waar die gesondheidsorgorganisasies nie daarin kan slaag om etiese sorg te verseker nie. Dit is om hierdie rede dat daar 'n behoefte is aan "individuele gewetens" wat alles nie sondermeer aanvaar en goedkeur wat in die gesondheidsorgsisteem gebeur nie. Die uitdaging is dat die publieke verwagting eerder die belang van die gesondheidsorgsisteem as individuele belang vooropstel. Die benadering is dat die "pasiënt eerste" gestel word om bestuurskundige redes en nie die etiese verhouding wat daar behoort te bestaan nie.

Hier gaan dit nie oor onetiese gedrag wat die lewe en / of gesondheid van die pasiënt in gevaar sal stel nie. Die bedoeling is eerder om beleid en verwagtings van die gesondheidsorgsisteem uit te wys. Beleid en verwagtings is nie noodwendig "oneties" nie, maar die toepassing van beleid kan maklik etiese spanning na vore bring veral waar die organisasie van sorg die enigste doel word: "Professionele ongehoorzaamheid betreft dan alles wat hulpverleners doen om openlijk te laten zien dat ze zich niet kunnen verzoenen met wat van hen wordt verwacht en gevraagd" (Vanlaere en Burggraeve, 2013: 115). Die bedoeling is nie net om die probleem uit te wys nie maar ook om daadwerklik op te tree. Dit gaan nie net oor die individu nie maar ook om 'n probleem bekend te maak. Daarom behoort daar kollektiewe ondersteuning van kollegas te wees. Die diepste motief van professionele ongehoorsaamheid is om 'n onbillike sisteem te verander sodat kwaliteit gesondheidsorg gelewer kan word. Die etiese imperatief kan dus nie oor die hoof gesien word nie. Vanlaere en Burggraeve (2013:121) vat die bedoeling hiervan saam as hulle opmerk: "Professionele ongehoorzaamheid is, kortom, een kwestie van ethiek."

Beide studies maak die leser bewus van die etiese uitdagings en dilemmas wat gesondheidsorgwerkers beleef. Die pleitrede is duidelik: sien die gesondheidsorgwerker se etiese nood óók raak. Hierdie studies wil verder 
beklemtoon dat die etiese gedrag van gesondheidsorgwerkers nie los gemaak kan word van die pasiënte wat hulle in hospitale, klinieke en privaat konsultasies versorg nie.

Hierdie twee studies bring verskeie vrae na vore: Word daar genoeg kennis geneem van die etiese uitdagings van gesondheidsorgwerkers? Is keuses in die gesondheidsorgetiek altyd die beste keuses? Is 'n nuwe verstaan van gesondheidsorgetiek nie nodig nie? Kan etiese opleiding help met die fasilitering van etiese keuses? Hoe behoort gesondheidsorgwerkers eties begelei te word?

Hierdie vrae, en meer, hang saam met die vraag van Eby, Hartley, Hodges, Hoffpauir, Newbanks en Kelley (2013) of gesondheidsorgwerkers beter opgelei kan word om eties te wees? Die agtergrond van hulle studie is toenemende gevalle van etiese wangedrag deur praktiserende verpleegpersoneel en -studente wat oneerlik in die leeromgewing is. Uit die studie wat onder doserende verpleegpersoneel gedoen is, bestaan die persepsie dat geloofsoortuigings die etiese gedrag van student stuur. Hoewel die afleiding gemaak kan word dat studente gesensitiseer kan word om eties te wees, is veral twee opmerkings van belang. Eerstens is die gedrag van akademiese personeel belangrik om integriteit te beklemtoon (rolmodel). Tweedens kan 'n ondersteunende etiese leeromgewing die gewenste gedrag moduleer.

Hierdie oorsig maak dit duidelik dat pasiënte, organisasie (beleid), eweknie ondersteuning (rolmodel) en opleiding (onderwys) belangrik is wanneer na die etiese versorging van gesondheidsorgpersoneel gekyk word.

\section{Aktualiteit van tema}

Dit is 'n aanvaarbare standpunt dat geen gesondheidsorg sonder behoorlike bio-etiese opleiding beoefen kan word nie. 'n Verslag van lidlande van die voormalige USSR, "The current state of bioethics education in the system of medical education in the CIS Member Countries" (Kubar, 2010) bevestig hierdie opmerking. Die verslag wys daarop dat wanneer gesondheidsorgwerkersinternasionaal wil deelneem daaraan internasionale bio-etiese standaarde voldoen moet word. Etiese gedrag is dus'n voorvereiste vir die beoefening van gesondheidsorg. Die onderskrywing van etiese gedrag moet nie bestaan net ter wille van internasionale samewerking 
nie, maar behoort deel van 'n algemene mensregtekultuur te wees. Hierdie perspektief word teruggevind in die Universele Menseregteverklaring (1948). Artikel 1 verwys na die reg op lewe en Artikel 25 na die reg op gesondheidsorg (United Nations Human Rights, 2015). Hierdie regte moet bydrae tot die sinvolle en waardige bestaan van die individu. 'n Etiese kultuur moet dus binne die gesondheidsorgomgewing bestaan en in stand gehou word. Die uitdaging is egter dat hoewel bio-etiek 'n internasionale vereiste is, is daar nie 'n gedeelde verstaan hiervan nie. Ten Have (2011:2122) wys daarop dat in Noord-Amerika en Wes-Europa die klem val op die etiese uitdagings wat die wetenskappe en nuwe tegnologieë na vore gebring het. In Latyns-Amerika gaan dit oor gelyke toegang tot mediese versorging as gevolg van die groot gaping tussen ryk en arm. In die Ooste gaan dit oor invloed op die gemeenskap of kollektief. Ten Have (2011) is reg as hy vra dat daar eenheid in die verskeidenheid moet wees. Regverdigheid, billikheid en respek moet aanwesig wees.

'n Verdere uitdaging in die gesondheidsorgetiek is die rol van finansies. In meeste samelewings kan die invloed van die mediese ekonomie op gesondheidsorg nie mis gekyk word nie (Remans, 2005). Finansies, of die gebrek aan finansies, is dus 'n vername rolspeler in die beoefening van die gesondheidsorgetiek. Hierby kan die argument van morele verantwoordelikheid gevoeg word teenoor gemeenskappe wat nie voldoende geld of gesondheidsorgwerkers het om basiese mediese dienste uit te rol nie. Wat duidelik behoort te wees, is dat in die vaslegging van 'n etiese kultuur moet toegang tot gesondheidsorg, menswaardigheid, wetenskap, tegnologiese ontwikkeling en kultuur in ag geneem word. 'n Basis reël behoort te wees dat niemand in vrees vir sy / haar lewe moet leef nie of in vrees moet lewe oor oortuiging, agtergrond of finansiële status nie.

Die ontwikkeling van mediese geesteswetenskappe (ook bekend as mediese menswetenskappe) ("medical humanities") staan nie los van hierdie menseregte kultuur nie. Verder is die bedoeling van die mediese geesteswetenskappe dat gesondheidsorgwerkers nie net die tegniese / wetenskaplike kennis van siekte en die terapeutiese en farmakologiese behandeling daarvan sal hê nie, maar dat hulle ook oor die nodige kennis sal beskik om met mense te kommunikeer, etiese uitdagings die hoof te kan bied en sosiale ekosisteme te kan verstaan. Ten Have (2011:36) is dus reg as 
hy wys op die multidissiplinêre karakter van bio-etiek. Verskeie dissiplines is nodig om tot ' $n$ sinvolle verstaan en toepassing van bio-etiek by te dra.

Binne die konteks van die mediese geesteswetenskappe is die doel onder meer om gesondheidsorgwerkers op te lei om etiese oordeel aan die dag te lê. In hierdie opleiding gaan dit nie net oor etiese gedrag en etiese keuses nie maar veral ook oor die verstaan van die etiese dekor van die gesondheidsorgbedryf. Binne hierdie konteks is 'n belangrike perspektief dat etiese handelinge nie net gaan oor beslissings tussen absolute goed en kwaad of reg en verkeerd nie. Wat ook nodig is, is om kennis te hê van morele konvensie (tradisie of gevestigde manier van doen) en begrip vir nuwe morele interpretasie (postkapitalistiese, postreligieuse, mobiliteit en kultuur-diverse konteks). Die argument wat bevorder word, is dat konvensionele etiese opleiding nie meer voldoende is om globale etiese probleme aan te spreek nie. 'n Bykomende argument is dat dit nie gaan net oor kennis van etiese probleme nie maar ook kennis van die konteks en die integrasie van etiese kennis in 'n bepaalde etiese raamwerk van waaruit etiese besluitneming geneem kan word.

\section{Standpunt en vertrekpunt}

Etiese oordeel is dikwels vasgevang in 'n tradisionele model - die tradisie (bekende gebruik) gee die pas aan en nie die konteks (omstandighede) of die uitdagings nie. Die etiese keuses waarvoor gekies word, is (amper) voorspelbaar: 'n mens weet wat die uitkoms gaan wees. Dit is veral die geval binne die gesondheidsorgetiek: gesondheidsorgwerkers is altyd toegewyd; praat altyd die waarheid; is nooit ongeduldig met hulle pasiënte nie en lewer onder alle omstandighede altyd 'n professionele diens. Hierdie is 'n tipiese bestuursbenadering aan die werk - optrede moet "meetbaar" wees. Die vraag is of dit is waaroor 'n sorg-etiek en sorgbenadering moet gaan? Is dit die kwaliteit van die sorg of die kwaliteit van die verhouding wat die sorg laat realiseer?

Ten einde die gesondheidsorgwerkers te ondersteun in hulle etiese gedrag teenoor pasiënte maar ook hulle eie etiese broosheid te ondersteun, kies die outeurs van hierdie studie vir 'n haalbare gasvryheids-en ontmoetingsetiek vir gesondheidsorgwerkers. Hiermee word bedoel dat die verwagtings, omstandighede en waardeoordele van die pasiënt, die gesondheidsorgwerker 
en die organisasie (as kollektief vir beleid, praktyk, sisteem en finansies) moet saamkom in 'n sorg-etiek. Hierdie etiese benadering word verder bevorder deur die rol wat etiese opleiding ("ethical coaching") hierin kan speel, die verstaan van 'n globale maar diverse bio-etiek en die "menslike aangesig" wat die mediese geesteswetenskappe na gesondheidsorg gebring het.

Die etiese gasvryheidsmodel berus op die navorsing van die Suid-Afrikaanse etikus, Robert Vosloo in sy boek: Engele as gaste? Die vertrekpunt van die studie is dat gasvryheid etimologies verwys na "vreemdelingsliefde". Dit beteken dat daar deernis en etiese gedrag teenoor die onbekende persoon bewys moet word. Gasvryheid word as 'n Bybelse deug beskou en gee erkenning dat ook vreemde mense beelddraers van God is. Die "ander" word as mede-beelddraer van God beskou. Hierdie verstaan van gasvryheid, naamlik omgee en erkenning is ononderhandelbaar vir die gesondheidsorg. Dit skep 'n gemeenskaplike platform waarbinne met mekaar omgegaan kan word. Gasvryheid beteken nie dat almal op gelyke vlak met mekaar in aanraking kan wees nie, juis as gevolg van die omstandighede. Dit beteken ook nie dat die verskille so groot is dat daar geen ruimte is waarbinne mense mekaar kan ontmoet nie. Gasvryheid vernou die brug tussen diversiteit van godsdiens, oortuiging, ras, geslag, kultuur en omstandighede. Gasvryheid skep opnuut die bewustheid dat mense in hulle diversiteit raakgesien, verstaan, ondersteun en versorg moet word. Gasvryheid skep 'n etiese intimiteit.

Vosloo se konsep van gasvryheidsetiek word in 'n etiek van ontmoeting gekomplementeer (Lategan, 2012). Hierdie etiese ontwerp berus op die boustene van etiek as handeling, morele liefde, onderlinge versorging en die omstandighede van die persoon. Aksie (optrede) en beweging (uitreik) speel 'n belangrike rol. In ontmoeting gaan dit oor die doelbewuste uitreik na die ander om fisiese, psigiese en/of materiële hulp en ondersteuning te bewys as onderlinge versorging en omgee van mekaar. Hierdie uitreiking word 'n doelbewuste uitdrukking van onderlinge liefde vir mense waarby ook die vreemdeling / onbekende persoon ingesluit is. Hierdie ontmoeting word gerig deur 'n gesindheid van naasteliefde wat deur verantwoordelike handelinge na mense uitreik ongeag wie hulle is of wat die omstandighede mag wees. Uitreik en verantwoordelikheid is dus 'n aangeleentheid waarvoor nie net een persoon verantwoordelik kan wees nie. Die doel 
van ontmoeting is om lewensverandering te weeg te bring. 'n Etiek vir ontmoeting word gevolglik verduidelik as die gesindheid van naasteliefde wat deur verantwoordelike handelinge na mense uitreik om ' $n$ waardegedrewe lewenservaring te ontwikkel en te ervaar.

Hierdie gasvryheids- en ontmoetingsetiek sluit by Burggraeve (1997) se "etiek van die haalbare" aan. Burggraeve werk met twee belangrike etiese konsepte, naamlik die etiek van die haalbare en 'n groei-etiek. Hierdie konsepte moet nie los van mekaar gedink word nie. In die etiek van die haalbare het 'n mens met kwesbare mense te doen vanweë die situasie. Mense in etiese dilemmas moet deur die kwesbaarheid van hulle omstandighede groei. Die etiek van die haalbare en groei-etiek vertrek vanuit die standpunt dat hoewel 'n mens na die ideale situasie moet strewe dit nie altyd moontlik is nie as gevolg van die omstandighede (situasie). Dit beteken nie dat as die ideale omstandighede verval, dan verval alle etiese gedrag nie. Etiese gedrag moet openbaar word ongeag die omstandighede. Hierdie etiese gedrag moet tot die omstandighede spreek. Binne 'n onvolmaakte wêreld moet daar etiese gedrag vir die onvolmaakte situasies ook wees (byvoorbeeld aborsie, genadedood en die bekamping van HIV/ Vigs). Die etiek van die haalbare herinner 'n mens juis daaraan dat etiese gedrag in onvolmaakte situasies nie afwesig moet wees nie. Die groei-etiek begelei 'n mens om vanuit die onvolmaakte situasie na die ideale situasie te groei. Onderliggend aan 'n groei-etiek is dat die etiese keuse wat gemaak word nie noodwendig die beste keuse mag wees nie maar dat daarna gestreef moet word om so na as moontlik aan die ideale situasie te kom. Christelike betrokkenheid, barmhartigheid en groei kan 'n mens juis help om by die ideale situasie uit te kom. Deelname behoort tot die etiese lewe en veronderstel betrokkenheid en verantwoordelikheid (Burggraeve, 2000: $48,52,81,107,118,122,196,198)$. Die waarde van 'n groei-etiek is voor die hand liggend. Groei-etiek verkondig dat iemand altyd na die ideale situasie moet strewe (byvoorbeeld om nie ongebore lewe te vernietig nie). Groeietiek erken ook dat dit nie altyd moontlik is nie (byvoorbeeld as gevolg van verkragting). Dit beteken nie dat die persoon veroordeel moet word nie. Inteendeel, mense in sulke situasies moet juis begelei word om die etiese gedrag te openbaar wat deur die morele verwagting onderskryf word. 


\section{Etiese verdieping}

Die etiese broosheid en versorging van gesondheidsorgwerkers word deur etiese dilemmas en besluitneming op die spits gedryf. Dit is hier waar die haalbaarheidsetiek 'n belangrike rol kan speel.

Lategan (2006) se studies oor die kompromie kom tot die slotsom dat in 'n botsing van pligte tussen die mindere van twee euwels gekies moet word. Mindere euwel verwys na die beste keuse in 'n onvolmaakte situasie. Hoewel die keuse nie die gewenste keuse is nie, was daar geen ander uitweg as juis hierdie keuse nie. Die bekendste voorbeeld is waar die volhou van 'n swangerskap die lewe van die moeder bedreig en dus moet die fetus / embrio geaborteer word. Lategan plaas hierdie keuse in die konteks van die Suid-Afrikaanse teoloog JA Heyns se dogmatiese ontwerpe van 'n gehoorsaamheidsteologie (1972) en kom tot die slotsom dat etiese gehoorsaamheid ook aanwesig moet wees in omstandighede waar daar nie volmaakte keuses bestaan nie. Maar omdat daar geen ander uitweg in die betrokke situasie is nie, word 'n keuse gemaak wat die beste vir die situasie is. Daarom staan 'n gehoorsaamheidsetiek voorop. Hier gaan dit om 'n keuse te maak wat die meeste etiese impak op die situasie sal hê. Die gehoorsaamheidsetiek is nou gekoppel aan die koninkryksmotief en het ten doel om Bybelse beginsels vir 'n situasie uit te wys en daardie beginsels binne die situasie toe te pas.

Burggraeve (1997) handel ook met etiese keuses en kom tot dieselfde slotsom naamlik dat in 'n onvolmaakte situasie 'n keuse gemaak moet word wat die beste binne die beskikbare omstandighede is. Sy aanslag en terminologie verskil. Volgens hom word vir die kleinste goed in 'n onvolmaakte situasie gekies. Vir hom gaan dit oor 'n etiek van die haalbare: dit is nie die keuse wat 'n mens sou wou uitvoer nie maar gegee die omstandighede word vir bepaalde optrede gekies hoewel die strewe na wat behoort te wees, nie geïgnoreer mag word nie. Etiek is dus morele ondersteuning ten spyte van morele uitdagings en tekortkomings. As agtergrond van Burggraeve se etiese ontwerpe is die invloed van Emmanuel Levinas duidelik sigbaar: die ontmoeting van die ander - die een vanuit sy magsposisie en die ander vanuit sy nood. Die etiese imperatief is om te help maar ook te bly streef na dit wat beter kan. 
Uit hierdie opmerkings kan drie belangrike afleidings gemaak word. Eerstens is etiese besluitnemings nie eenvoudig nie. Tweedens wil etiese besluitneming juis die beste optrede in 'n situasie verseker. Derdens kan geen besluitneming buite 'n etiese verwysingsraamwerk geneem word nie.

Hierdie verstaan van die gehoorsaamheids- en haalbaarheidsetiek maak 'n verdere saak duidelik naamlik dat etiese dilemmas aktiewe optrede vra. Hierna kan verwys word as etiese moed ("ethical courage"). Etiese moed beteken dat 'n mens nie 'n saak sal ignoreer nie maar daadwerklik optree om die beste besluit vir hierdie omstandighede te neem. Die moed waarna hier verwys word, kan ook verstaan word teen die agtergrond van vrymoedigheid. Dit gaan nie om te sê wat 'n mens dink nie maar die persoonlike verbintenis daaraan (Vanlaere en Burggraeve, 2013:122-127).

In hierdie konteks kan die sogenaamde "Georgetown mantra" 'n waardevolle bydrae lewer. Etici en filosowe aan die Universiteit van Georgetown, Washington DC, het vier leidende etiese beginsels geformuleer wat gebruik kan word om etiese probleme te analiseer en etiese vrae te beantwoord. Hierdie beginsels is die respek vir individuele outonomie, goed doen aan ander, niemand skade berokken nie en regverdigheid. Na hierdie beginsels word as die Georgetown mantra verwys om hiermee te sê dat dit byna 'n "heilige" teks is waaroor nie verder besin hoef te word nie (sien Ten Have, 2011:27,28). Ten Have (2011) lewer belangrike kommentaar hierop: Hy sê dat behalwe die beginsel van regverdigheid is daar geen oriëntasie op die gemeenskap, samelewing of leefwêreld in die algemeen nie. Hierdie is belangrike perspektief in die etiese begeleiding van gesondheidsorgwerkers en kan nie sondermeer geïgnoreer word nie.

\section{Nog'n keer: Etiese uitdagings vir gesondheidsorgwerkers}

Die studie van Vanlaere en Burggraeve (2013) verdien verdere aandag. Hulle benadering is om die hardnekkige stereotipering van gesondheidsorg te deurbreek. Hulle standpunt is dat gesondheidsorgwerkers beperkte kennis het (weet nie alles nie) en dat hulle optrede feilbaar is (hulle is mense wat ook etiese versorging nodig het en hulle optrede kan ook etiese vrae oproep). Hulle stel dit duidelik: "Daarom precies zijn wij ervan overtuigd dat ethiek ook rekening moet houden met de ethische kwestbaarheid van zorgdragers ..." (Vanlaere en Burggraeve, 2013: 11). 
Die probleem word vererger deur middelmatigheid as gevolg van tydsgebrek, gebrekkige kommunikasie, tekort aan medewerkers en hulpbronne (Vanlaere en Burggraeve, 2013: 56). Nader bekyk, bestaan middelmatigheid deur die feit dat daar nie altyd voldoende middels is om sorg te bied nie. Hieraan kan dikwels niks gedoen word nie. Maar middelmatigheid kan ook bestaan omdat daar nie iets aan die uitermatige lyding van pasiënte gedoen kan word nie.

Die tragedie is dat kennis aan tegniese vaardigheid gemeet word maar nie die manier waarop met pasiënte omgegaan word nie (Vanlaere en Burggraeve, 2013: 61-62). Betrokkenheid by ander is nie ' $n$ rasionele keuse nie maar hoe' $n$ mens getrek word deur die swaarkry van ander (Vanlaere en Burggraeve, 2013: 59-60). Wat nodig is, is om te vra hoe kan dit beter - dit is waaroor sorg gaan (Vanlaere en Burggraeve, 2013: 64). Dit is noodsaaklike dat mense hulle eie beperkings ken - die mens is immers geen god of engel nie. Insig in 'n mens se eie omstandighede is juis bevrydend:

"Die bescheidenheid is noodzakelijk om zich als zorgdraer niet van de ander af te keren. Pas wanneer zorgdragers de grenzen van hun eigen vermogen kennen, krijgen ze immers ruimte voor de ander" (Vanlaere en Burggraeve, 2013: 65).

Etiese houding is nie iets wat sporadies plaasvind nie. Dit word ondersteun deur 'n ingesteldheid hoe met ander mense omgegaan word. Sorg vind nie eers plaas wanneer iets konstruktiefs aan ander gedoen word nie (Vanlaere en Burggraeve, 2013: 29, 30). Die verhouding tussen pasiënt en gesondheidsorgwerker is baie belangrik. Tyd speel hier 'n belangrike rol. Deur tyd moet ruimte ook vir ander geskep word om op 'n situasie te reageer:

"Ethisch beslissen is pas mogelijk als er ook bedachtzaamheid aan de dag wordt gelegd. Bedachtzaamheid beteken eigenlijk dat we niet te vlug een oordeel moeten vellen, maar ons het best eerst onthouden van het vellen van een oordeel. Daardoor geven we de ander de tijd om zich te laten zien en kunnen we zelf de tijd nemen om goed naar ander te kijken" (Vanlaere en Burggraeve, 2013: 49). 
Hulle bevorder die gedagte van "kleine goedheid" - dit wat daagliks maar amper onopsigtelik plaasvind. Dit gaan oor 'n teenwoordigheid in die lewe van die pasiënt (Vanlaere en Burggraeve, 2013: 67,68).

Vanlaere en Burggraeve (2013: 9) wys op die wêreldwye verskynsel dat die ideale beeld van gesondheidsorg voorgehou word. Hoewel dit inspirerend is, kan dit soveel druk op gesondheidsorgwerkers plaas met die gevolg dat dit presies die teenoorgestelde optrede tot gevolg sal hê.

Uit hierdie studie kan twee afleidings gemaak word: eerstens is daar persoonlik-etiese uitdagings. Gesondheidsorgwerkers en pasiënte se verwagtings en etiese oordeel verskil. Tweedens is daar die invloed van sosio-ekosisteme wat etiese besluitneming beïnvloed.

'n Groot probleem is egter dat daar baie min plek vir bio-etiek in die mediese kurrikulum is (Vanlaere en Burggraeve 2013: 29). Remans (2005: 89) ondersteun die noodsaaklikheid van beroepsetici wat gesondheidsorgwerkers in hulle bio-etiese kwessies begelei en ook etiese komitees wat na die etiese aspekte van hospitale moet omsien. Phalime (2014: 134) sluit hierby aan. Die etiese uitdaging is nie altyd die werk nie maar die opleiding wat in baie gevalle ontoereikend is. Dit sluit aan by 'n bevinding van Eby et al. (2013) dat 'n etiese raamwerk ondersteunend is in die vaslê van etiese gedrag.

Die vraag is nou hoe 'n haalbare gasvryheids- en ontmoetingsetiek hierdie uitdagings kan oorbrug?

\section{Die rol van 'n haalbare gasvryheids- en ontmoetingsetiek in die opleiding van gesondheidsorgwerkers}

In hierdie studie is geargumenteer dat 'n haalbare gasvryheids- en ontmoetingsetiek ' $n$ bydrae tot effektiewe sorg-etiek kan lewer. Hierdie etiese ontwerpe wil 'n bepaalde perspektief bevorder wat in die opleiding van gesondheidsorgwerkers gebruik kan word.

Die vertrekpunt is die kwaliteit van die sorg. Die keuse val nie op 'n bestuursmodel en metingsinstrument waardeur die kwaliteit gemeet kan word in terme van tydsduur, koste, effektiwiteit en hoe tevrede kliënte is nie. Die fokus is op die kwaliteit van die sorgverhouding tussen pasiënt en gesondheidsorgwerker. Vanuit hierdie vertrekpunt oor die kwaliteit van 
gesondheidsorg neem 'n haalbare gasvryheids- en ontmoetingsetiek 'n bepaalde posisie in.

'n Ontmoetingsetiek veronderstel die beskikbaarheid vir die ander persoon - die beskikbaarheid om sorg te lewer (gesondheidsorgwerker) maar ook te ontvang (pasiënt). Beskikbaarheid veronderstel verder dat mense wedersyds by mekaar aanmeld sodat die een van die ander kan ontvang. Ontmoeting skep 'n gemeenskaplike grond wat alle magsverhoudings afbreek - die mediese kennis van die gesondheidsorgwerker word nie 'n bedreiging nie net soos die kliëntestatus van die pasiënt nie die voortdurende vrees skep vir moontlike regsgedinge nie.

'n Gasvryheidsetiek breek die kulturele, godsdienstige, politieke en sosioekonomiese skeiding tussen mense af. 'n Gasvryheidsetiek skep ruimte om met mekaar in 'n verhouding te kan tree. Die verhouding is gebou op die waardes van respek, medelye, omgee, empatie en verdraagsaamheid. 'n Gasvryheidsetiek veronderstel 'n gedeelde menservaring en ideologiese neutraliteit. Gasvryheid versinnebeeld dat een mens die ander aanvaar ongeag die agtergrond van die persoon of die omstandighede waarin die persoon verkeer.

'n Haalbare etiek streef daarna dat die verhouding altyd beter kan. Die vertrekpunt is dat die ideale / perfekte omstandighede dalk nie moontlik mag wees nie, maar dat daar voortdurend daaraan gewerk moet word. Dit is hier waar die groei in die kwaliteit van die verhouding in sig kom. 'n Haalbaarheidsetiek is net moontlik wanneer diekwaliteit van dieverhouding 'n gemeenskaplike prioriteit vir beide pasiënt en gesondheidsorgwerker is.

'n Haalbare gasvryheids- en ontmoetingsetiek se betekenis vir die etiese versorging van die gesondheidsorgwerker maak die pasiënt en organisasie daarvan bewus dat die persoon en omstandighede van die gesondheidsorgwerker in die behandeling en versorging van pasiënte raakgesien moet word. Dit vra dat ook die gesondheidsorgwerker in sy/haar omstandighede ontmoet moet word. Die gesondheidsorgwerker het ook die reg op lewe en die beskerming van daardie lewe. Net soos die pasiënt se gesondheid verbeter moet word, moet ook die gesondheidsorgwerker se gesondheid in stand gehou word. 'n Haalbare gasvryheids- en ontmoetingsetiek word 'n spieëlbeeld waarin 'n gemeenskap sy gesondheidsorgwerkers moet raaksien en ondersteun. 


\section{Toepassing}

In 2008 is in Vlaandere 'n "sorg-etiese laboratorium" opgerig met die oog op die etiese ontwikkeling van gesondheidsorgwerkers vanuit die perspektief van 'n haalbare gasvryheids- en ontmoetingsetiek. Hierdie "laboratorium" wat as sTimul bekend staan, het ten doel om ervaringsleer aan te bied deur realistiese sorgsituasies na te boots of te simuleer. Hier kry gesondheidsorgwerkers die geleentheid om oor twee dae as "kwesbare pasiënte" opgeneem te word. Oor hierdie twee dae word hulle deur finalejaar verpleegkunde studente verpleeg asof hulle werklik pasiënte binne die gesimuleerde omstandighede is. Aan die einde van hierdie twee dae kry die gesondheidsorgwerkers as gesimuleerde pasiënt en die studente dan die geleentheid om op hulle ervaring te reflekteer.

Vir die gesondheidsorgwerkers as gesimuleerde pasiënte is hierdie ervaring dikwels 'n openbaring omdat hulle as "pasiënte" aan die "ontvangkant" van sorg is. Die waarde hiervan is dat dit die gesondheidsorgwerker laat nadink oor die manier waarop hulle pasiënte versorg. Uit opvolg onderhoude blyk dit dat hierdie ervaring gesondheidsorgwerkers voortdurend oor hulle eie praktyke laat besin. Gevolglik kyk hulle nou meer na die versorging van pasiënte uit die perspektiefvan'n pasiënt as die van'n gesondheidsorgwerker (sien Vanlaere, Timmermann, Stevens en Gastmans, 2012).

Naas hierdie pasiënt gesentreerde fokus is 'n verdere toegevoegde waarde dat pasiënte sorg ontvang wat vir hulle omstandighede toepaslik is (Baart en Grypdonck, 2008). Dit is net moontlik as die gesondheidsorgwerker "sien" watter uitdagings die pasiënt het. Hierdie "sien" sny veel dieper as wat dit wat waarneembaar is. Eerstens omdat pasiënte nie altyd hulle eie kwesbaarheid kan verwoord nie. Tweedens omdat die gesondheidsorgwerker hom/haar nie in die posisie van die pasiënt se belewenis van siekte kan plaas nie. Derdens omdat gesondheidsorgwerkers nie geredelik beskikbaar is om in die behoeftes van pasiënte te voorsien nie. Vierdens omdat pasiënte nie altyd die vrymoedigheid of vermoë het om hulle behoeftes te verwoord of te kommunikeer nie.

Die gesondheidswerkers wat die simulasie laboratorium bywoon, kan met beter begrip praat oor die behoeftes van die pasiënt. Die simulasie laboratorium bied die unieke geleentheid om gekontroleerd 'n ervaring van 'n pasiënt te hê. Die ervaring leer dat die gesondheidsorgwerker 'n nuwe 
begrip vir die behoeftes van pasiënte ontwikkel het. Binne hierdie raa mwerk leer die gesondheidsorgwerker "kyk" (kliniese beeld) na die pasiënt maar ook die emosionele en persoonlike behoefte te "sien" (individuele behoefte).

In die simulasie-laboratoruim word ook aandag aan die etiese ontwikkeling van die gesondheidsorgwerker gegee. Hier is die geleentheid om etiese dilemmas te ervaar en daarop te reflekteer. Tipiese voorbeelde is die tyd waarop die pasiënt aandring en die tyd wat die gesondheidsorgwerker beskikbaar het; die aandag wat die pasiënt vra teenoor die aandag wat sy/ haar behoefte verdien en dit wat die gesondheidsorgwerker graag wil doen teenoor dit wat moontlik is in terme van beskikbare tyd en hulpbronne. Hoe met hierdie spanning omgegaan word, dra by tot die etiese ontwikkeling van die gesondheidsorgwerker. Sonder hierdie etiese ontwikkeling bly die gesondheidsorgwerker kwesbaar en nie in staat om optimaal te funksioneer nie. Die gevolg is dat byvoorbeeld 'n verpleegster in opleiding reeds negatief teenoor die beroep staan voordat sy die beroep professioneel betreë het.

Die manier waarop dosente in gesondheidsorgdissiplines met etiese opleiding omgaan, verdien ook die aandag (Vanlaere, 2014). 'n Eerste probleem is dat die opleiding en ervaring van dosente dikwels beperk is tot teoretiese kennis. Nog 'n probleem is dat die opleiding dikwels konseptueel van aard is. Hierdie toedrag van sake maak etiese opleiding dikwels ontoereikend wat verder bydrae tot die etiese kwesbaarheid van gesondheidsorgwerkers. Dit is hier waar die gesimuleerde laboratorium gebruik kan word om hierdie leemte in etiese opleiding aan te vul.

\section{Samevatting}

In hierdie studie het die outeurs die aandag laat val op die rol wat'n haalbare gasvryheids- en ontmoetingsetiek kan speel in die etiese kwesbaarheid van die gesondheidsorgwerker. Die twee studies uit Suid-Afrika (Phalime) en België (Vanlaere en Burggraeve) het die etiese kwesbaarheid van gesondheidsorgwerkers toegelig. Hierdie kwesbaarheid is die resultaat van etiese spanning in die werkplek, die verwagtings en behoeftes van die pasiënt of persoonlike omstandighede van die gesondheidsorgwerker. Hierdie studie het voorgestel dat daar enersyds beter begrip van etiese uitdagings moet wees. Hier kan die haalbare gasvryheids- en ontmoetingsetiek 'n rol speel. Opleiding en blootstelling aan etiese uitdagings in die werkplek is 
van uiterste belang. Hier kan 'n gesimuleerde laboratorium-ervaring soos sTimul van waarde wees.

Die bydrae wat hierdie studie wil maak, is om 'n raamwerk aan te bied waarbinne oor gesondheidsorgwerkers se etiese kwesbaarheid nagedink kan word en die rol wat opleiding kan speel om hierdie uitdaging aan te spreek.

\section{Literatuur}

Baart, A \& Grypdonck, M 2008. Presentie en verpleegkunde. Een zoektocht in dialoog naar de betekenis van presentie voor verpleegkundige zorg. Den Haag: Lemma.

Burggraeve, R 1997. Een christelijke ethiek van het haalbare. In Wuyts, B. (Red). De geest rust nooit: gelovigen in beweging. Kapellen: Patmos. 143-152.

Burggraeve, R 2000. Ethiek en passie. Over de radicaliteit van christelijk engagement. Tielt: Lannoo.

Eby, RA, Hartley, PL, Hodges, PJ, Hoffpauir, R, Newbanks, S \& Kelley, JH 2013. Moral integrity and moral courage: can you teach it? Journal of Nursing Education, 52(4): 229-233.

Heyns, JA 1972. Lewende Christendom. 'n Teologie van Gehoorsaamheid. Kaapstad: Tafelberg.

Kubar, OI (Ed) 2010. The current state of bioethics education in the system of medical education in the CIS member countries: an analytical review. Unesco.

Lategan, LOK 2006. Die gemengdheid van die lewe: Die minste goed of die mindere euwel? Tydskrif vir Christelike Wetenskap. Spesiale uitgawe. 42:95-109.

Lategan, LOK 2012. Etiek van ontmoeting. Tydskrif vir Christelike Wetenskap, 49(3 \& 4): 157-178.

Phalime, M 2014. Postmortem: the doctor who walked away. Cape Town: Tafelberg. 
Remans, J 2005. De boom van goed en kwaad: Over bio-ethiek, biotechniek, biopolitiek. Leuven / Voorburg: Acco.

Ten Have, H 2011. Bioethiek zonder grenzen. Mondialisering van gezondheid, ethiek en wetenschap. gp: Valkhof Pers.

United Nations Human Rights. 2015. Universial Declaration of Human Rights 1984 [Intyds]. Beskikbaar: http://www.ohchr.org [15 Junie 2015].

Vanlaere, L 2014. Response to commentary 2: A view from sTimul. Nursing Ethics, 21(6):744-745.

Vanlaere, L, Timmermann, M, Stevens, M \& Gastmans, C 2012. An explorative study of experiences of healthcare providers posing as simulated care receivers in a "care-ethical" lab. Nursing Ethics, 19(1):68-79.

Vanlaere, L \& Burggraeve, R 2013. Gekkenwerk: kleine ondeugden voor zorgdragers. Tielt: Uitgeverij Lannoo Campus.

Vosloo, R 2006. Engele as gaste? Oor gasvryheid teenoor ander. Wellington: Lux Verbi BM. 